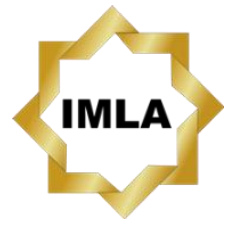

Available online:

http://journal.imla.or.id/index.php/arabi

Arabi : Journal of Arabic Studies, 3 (2), 2018, 167-180

DOI: http://dx.doi.org/10.24865/ajas.v3i2.110

\title{
MODERNISME PEMBELAJARAN BAHASA ARAB BERBASIS PESANTREN DI RANGKASBITUNG BANTEN
}

\author{
Abd. Rozak \\ Universitas Islam Negeri Syarif Hidayatullah Jakarta, Indonesia \\ E-mail : rozak@uinjkt.ac.id
}

\begin{abstract}
This study aimed to analyze the strengths, weaknesses, opportunities, and challenges in learning Arabic in traditional and modern Islamic boarding schools (pesantren) in Lebak Regency, Banten. This was a qualitative research. The researcher directly reviewed the curriculum and learning documentsand observed learning Arabic at both pesantrens. The ongoing learning was studied, understood, described, analyzed, and criticized. The results showed that the education system of modern pesantren was more open to study contemporary books in addition to classical books with the main target of being fluent in Arabic (maharah al-kalam). One of the distinctive characteristics of modern pesantren is that the languages spoken by all elements of this institution are Arabic and English as an attempt to meet the challenges in the era of globalization.
\end{abstract}

Keywords: modern boarding schools; Arabic learning; orientation; tradition; motivation

\begin{abstract}
Abstrak
Penelitian ini bertujuan untuk menganalisis berbagai kekuatan, kelemahan, peluang, dan tantangan yang terdapat pada pembelajaran bahasa Arab di pondok pesantren tradisional dan modern di Kabupaten Lebak Propinsi Banten. Penelitian ini merupakan penelitian kualitatif dengan jenis penelitian lapangan (field research). Peneliti secara langsung mengkaji kurikulum, dokumen-dokumen pembelajaran, dan pembelajaran bahasa Arab pada pondok pesantren tradisional dan modern. Peneliti mempelajari, memahami, menggambarkan, menganalisis, dan mengkritisi pembelajaran yang berlangsung. Hasil penelitian menunjukkan bahwa sistem pendidikan pondok pesantren modern lebih terbuka untuk mempelajari kitab/kitab kontemporer di samping kitab/kitab klasik dengan target utama lancar berbicara dalam bahasa Arab (maharah al-kalam). Salah satu ciri khas pondok modern adalah bahasa yang digunakan oleh elemen pondok pesantren modern adalah bahasa Arab dan bahasa Inggris sebagai upaya menjawab tantangan zaman yang dilaluinya.
\end{abstract}

Kata Kunci: pondok pesantren modern; pembelajaran bahasa Arab; orientasi; tradisi; motivasi 


\section{Arabi : Journal of Arabic Studies}

\section{Pendahuluan}

Bahasa adalah sebuah produk budaya yang sekaligus berarti produk sosial suatu masyarakat. Sebuah kecenderungan budaya untuk mengatakan hal-hal tertentu, sebagai suatu kompetensi linguistik yang spesifik untuk mengatakan sesuatu "secara benar" dan kapasitas sosial untuk menggunakan kompetensi itu secara tepat (Winarsih, 2013).

Berbicara mengenai bahasa Arab, kalangan pebelajar Indonesia memberikan kesan yang menunjukkan bahwa bahasa tersebut sulit dan rumit untuk dipelajari. Setiap bahasa yang ada di dunia ini menurut teori linguistik memiliki level kemudahan dan kesulitan yang beraneka ragam sesuai dengan ciri khas yang ada pada sistem bahasa itu, baik secara fonologi, morfologi, maupun sintaksis, dan semantiknya. Ketekunan dan kesabaran sangat dibutuhkan oleh setiap orang yang mempelajari bahasa Arab. Persepsi sulit mempelajari bahasa Arab muncul karena terdapat perbedaan antara bahasa Arab dengan bahasa Indonesia, terutama sistem tata bunyi (fonologi), tata bahasa (nahwu dan sharaf), kosakata (mufradāt), gaya bahasa (ushlüb), serta tulisan (imlā') (Garancang, 2010).

Bahasa Arab memiliki karakter yang sangat berbeda dengan bahasa asing lainnya, seperti bahasa Inggris dan Indonesia. Hal ini menjadi salah satu faktor penghambat pembelajaran keterampilan bahasa Arab yang efektif. Oleh karena itu, kajian kontrastif antara kedua bahasa sangat diperlukan untuk memberikan solusi penyelesaian masalah tersebut (Ahmadi, 2014).

Sosiokultural bahasa Arab berbeda dengan sosiokultural bangsa Indonesia. Bahasa Arab dan bahasa Indonesia memiliki perbedaan dari segi ungkapan-ungkapan, istilah-istilah, ataupun namanama benda. Hal tersebut membutuhkan penyusunan materi pelajaran bahasa Arab yang mengandung hal-hal yang dapat memberikan gambaran sekitar sosiokultural bangsa Arab sangat dibutuhkan. Namun hal tersebut belum terpenuhi dengan baik dalam pembelajaran bahasa Arab selama ini.

Bahasa Arab merupakan produk budaya bangsa Arab yang mempunyai dimensi akademik, humanistik, dan pragmatik. Fakta menunjukkan bahwa banyak kalangan terpelajar di berbagai belahan dunia, baik muslim maupun non-muslim, melakukan penelitian bahasa Arab untuk kepentingan akademik ataupun non akademik. Namun sangat disayangkan kesan sulit dan rumit yang membayangi bahasa Arab dikhawatirkan menjadi bumerang yang menyebabkan ketidakberhasilan dan ketidakefektifan pembelajaran bahasa Arab. Hal ini merupakan pekerjaan rumah untuk para ahli dan pendidik bahasa Arab agar dapat memberikan solusi untuk permasalahan tersebut (Abd Wahab, 2009).

Hasil penelitian Aziz Fahrurrozi pada tahun 2014 menunjukkan bahwa banyak faktor yang menyebabkan keberhasilan pembelajaran bahasa Arab belum memadai, salah satunya adalah persoalan metode pembelajaran. Oleh karena itu, paradigma pembelajaran bahasa Arab harus dialihkan dari sekedar alat spiritualisasi menuju alat saintifikasi dengan didukung kebijakan pemerintah negara-negara berpenduduk mayoritas muslim (Fahrurrozi, 2014).

Dalam perjalanannya yang sangat panjang, perkembangan pembelajaran bahasa Arab yang terjadi di Indonesia bisa dikatakan jalan di tempat. Pembelajaran bahasa Arab selama ini belum mampu menjawab tantangan zaman. Pernyataan tersebut tentunya dilandaskan pada beberapa pengamatan terstruktur terhadap perkembangan bahasa Arab di Indonesia, dan agaknya patut juga untuk dipertimbangkan (Handriawan, 2015).

Kenyataan tersebut menggiring banyak orang dan banyak kalangan pemerhati pembelajaran bahasa Arab di Indonesia mempersoalkan masalah efektifitas kurikulum pembelajaran bahasa Arab di Indonesia yang sampai saat ini, baik dari aspek isi materinya, maupun aspek metodologi pengajarannya, disinyalir belum mampu mengimbangi peningkatan peran bahasa Arab di kancah Internasional. Sebenarnya banyak pihak yang ikut bertanggung jawab terhadap masalah ini. Mulai dari strategi pembelajarannya yang mungkin kurang tepat, media pembelajaran yang samasekali tidak memadai, minimnya innovasi dalam pembelajaran sampai pada kompetensi guru bahasa Arab sebagai hasil studinya pada pendidikan Tinggi yang mungkin saja gagal (Islam, 2015). 
Kemampuan berkomunikasi interpersonal, baik secara aktif maupun pasif bisa diibaratkan as the core of the bahasa Arab, dan begitu juga bahasa-bahasa lain. Namun, fakta berbicara, kurikulum-kurikulum bahasa Arab di Indonesia, ternyata sebagian besar masih berorientasi pada pembelajaran bahasa Arab preskriptif bukan deskriptif dan kurang peduli terhadap fenomena bahasa Arab yang dewasa ini berkembang pesat dengan segala bentuk transformasi kosakata, maupun pemakaiannya. Bahasa Arab di Indonesia, dalam konteks pembelajaran, sepertinya masih baru diposisikan pada tataran preskriptif saja dan belum beranjak dewasa.

Kurikulum merupakan pedoman pelaksanaan pembelajaran yang diorentasikan untuk mencapai tujuan pembelajaran, begitupula dalam pembelajaran bahasa Arab Kurikulum pembelajaran bahasa Arab selama ini seringkali dinilai kurang produktif, terlalu gemuk dengan materi, dan terorientasi dengan kompetensi akhir yang harus dimiliki oleh peserta didik. Pembelajaran bahasa Arab yang diselenggarakan selama ini hanyalah berpola untuk memindahkan isi dari pengajar ke peserta didik, sehingga pembelajaran menjadi monoton, satu arah dari pengajar ke peserta didik, dan membosankan.

Selain itu, tidak adanya tindak lanjut pembelajaran Bahasa Arab juga menjadi problem tersendiri dalam pembelajaran, perkuliahan bahasa Arab hanya dilaksanakan pada semester pertama, setelah itu apa yang telah mereka pelajari nyaris tidak digunakan. Padahal bahasa adalah sebagai alat komunikasi, jika tidak pernah digunakan, maka seseorang tidak akan menguasainya. Oleh karena itu, pembelajaran bahasa Arab tidak akan bisa dipahami jika diajarkan satu semester tanpa dilakukan tindak lanjut.

Pengembangan pembelajaran bahasa Arab pada saat ini belum sepenuhnya dilandasi oleh hasil-hasil penelitian tentang bahasa Arab secara memadai. Sehingga materi ajar bahasa Arab itu menjadi kurang menarik dan tidak relevan dengan kebutuhan siswa. Kurikulum bahasa arab hendaknya disusun berdasarkan atas berbagai aspek, di antaranya kebutuhan siswa, masyarakat dan pelaku pendidikan. Bahasa arab tidak dapat dilihat hanya sebagai bahasa agama, namun juga harus dilihat sebagai salah satu bahasa dunia. Semenjak adanya pengakuan masyarakat Internasional terhadap bahasa Arab, maka semakin jelas bahwa bahasa arab menempati posisi penting dalam ruang lingkup internasional. Masyarakat internasional terutama negara-negara maju, seperti Eropa dan Amerika Serikat, mulai tertarik untuk mempelajari sekaligus menggunakan bahasa ini sebagai media komunikasi.

Adapun pengajar merupakan salah satu faktor yang menentukan dalam interaksi pembelajaran sebagai sumber belajar utama mahasiswa untuk memahami sesuatu, termasuk pada pembelajaran bahasa Arab (Rianto, 2014). Apabila pengajar bahasa Arab tidak memiliki pengetahuan yang cukup luas tentang bahasa Arab, maka tentu ia tidak berkompoten dalam mentrasfer pengetahuan bahasa Arab tersebut. Seorang pengajar bahasa Arab minimal memiliki 3 hal untuk mampu mengajarkan bahasa Arab, yaitu: kemahiran berbahasa Arab, pengetahuan tentang bahasa Arab, serta keterampilan mengajarkan bahasa Arab. Terkadang pengajar kurang terampil dalam mengajar atau kurang berkemampuan menerapkan metode pembelajaran yang variatif dan menarik perhatian mahasiswa. Hal ini menyebabkan model pembelajaran bahasa terasa membosankan dan kaku, sehingga mengakibatkan pebelajar cenderung menghindari belajar bahasa Arab (Effendy, 2005).

Selain itu, pengetahuan beberapa pengajar tentang sistem pembelajaran bahasa Arab masih minim, sehingga belum mampu menghadapi kendala-kendala metodologis pembelajaran secara komprehensif. Pengetahuan beberapa pengajar tentang metode pembelajaran bahasa Arab masih sangat minim, sehingga kemampuan untuk melakukan inovasi pembelajaran masih belum dilakukan secara maksimal, misalnya penggunaan media dan sumber belajar sebagai penopang metode masing sangat kurang (Muradi, 2016). Hal ini dibuktikan dengan pembelajaran yang masih didominasi oleh penggunaan metode-metode tradisional, seperti penggunaan metode ceramah, metode menghafal, dan metode gramatika terjemah. 


\section{Arabi : Journal of Arabic Studies}

Kejenuhan dalam belajar bahasa Arab terjadi karena mereka belum memahami bahasa dengan baik (Subur, 2006). Berdasarkan pengamatan peneliti terlihat memang pebelajar yang mampu dan termotivasi belajar berbahasa Arab adalah mahasiswa yang mempunyai basic pondok pesantren. Sedangkan mereka yang tamatan Madrasah Aliyah dan sekolah umum, secara umum mereka menjadi jenuh untuk belajar bahasa Arab.

Terlepas dari persepsi tersebut, kesulitan dalam pembelajaran bahasa Arab bukan hanya disebabkan oleh faktor psikologis dan sosial (pencitraan), namun juga disebabkan oleh faktor metodologis (linguistik). Permasalahan metodologis berhubungan dengan bagaimana materi itu diseleksi, dikemas, dan disampaikan kepada siswa sehingga dapat dipraktikkan dengan efektif (Azzuhri, 2009).

Model pembelajaran dengan berfokus kepada satu keterampilan saja tidak lagi relevan, sebab bahasa Arab sebagai bahasa internasional tidak lagi hanya berfungsi sebatas bahasa agama, akan tetapi telah menjadi media komunikasi dalam seluruh aspek kehidupan. Bahasa Arab tidak lagi cukup hanya dikuasai secara pasif dalam bentuk penguasaan gramatika dan keahlian menerjemah, akan tetapi harus dikuasai secara komunikatif, baik lisan maupun tulisan. Bahkan masih banyak di kalangan masyarakat kita bahwa orang yang hafal sekian bait dari kitab $N a \underline{h} w$ dianggap mumpuni dalam bahasa arab meskipun tidak bisa berbicara bahasa Arab dengan fasih.

Model pembelajaran tradisional memberikan porsi yang sangat besar terhadap kaidah-kaidah bahasa Arab daripada kemampuan yang lain. Semua itu menjadi bukti tentang adanya grammaroriented yang sangat kuat dalam pembelajaran bahasa Arab di Indonesia. Pada awal-awal bahasa Arab diajarkan metode ini memang sangat diminati karena merupakan metode yang paling tua dalam pembelajaran bahasa Arab (Thu'aimah, 1989). Inovasi dalam pembelajaran bahasa Arab sangar diperlukan agar dapat memersiapkan para pebelajar yang mampu mengaktualisasi kemampuan bahasa Arab dalam segala bidang; ia pandai membaca kitab kuning serta memahaminya dengan benar dan juga memiliki kemampuan mendengar yang baik dan kemampuan berbicara yang fasih.

Sementara itu, penggunaan metode dalam pembelajaran bahasa Arab sangat bergantung kepada prinsip dan konsep yang dipahami oleh pengajar. Sebuah metode sangat berkaitan dengan aspek-aspek pembelajaran lainnya, baik metode tradisional maupun modern (inovatif). Oleh karena itu, seorang pengajar diharuskan memahami kelebihan dan kelemahan di antara keduanya demi tercapainya pembelajaran bahasa Arab yang efektif (Sapri, 2008).

Pembelajaran bahasa Arab untuk penutur asing sangat membutuhkan metode yang berbeda dengan kebutuhan pebelajar dari penutur Arab. Pebelajar dalam penutur Arab memiliki karakter yang berbeda dengan pebelajar dalam penutur asing. Oleh karena itu, seorang guru harus pandai memerhatikan berbagai karakter para siswa dalam rangka memeroleh hasil pembelajaran yang efektif.

Metode pembelajaran bahasa Arab masih menjadi permasalahan utama penyebab ketidakberhasilan siswa dalam menguasai keterampilan bahasa Arab. Tidak sedikit pengajar yang menggunakan metode ceramah untuk mengajarkan keterampilan membaca dan menulis. Oleh karena itu, seorang guru harus memiliki wawasan luas tentang metode pembelajaran dan memilih metode yang tepat untuk pembelajaran bahasa bagi penutur asing.

Namun sayangnya, pemilihan metode pembelajaran masih terkendala pada perbedaan kemampuan siswa, baik itu kemampuan dasar bahasa yang disebabkan oleh perbedaan latar belakang pendidikan, atau kemampuan pendukung lainnya seperti kemampuan menghafal, sehingga metode tidak dapat dilaksanakan secara maksimal dalam proses pembelajaran. Selain itu, kondisi/suasana pembelajaran yang dilakukan pada waktu dimana kondisi fisik pebelajar tidak segar dan fit, misalnya di jam-jam terakhir atau setelah mata pelajaran eksakta, juga termasuk faktor eksternal yang menjadikan aplikasi metode pembelajaran tidak efektif.

Berbagai fakta tersebut di atas menunjukkan bahwa komponen proses dalam pembelajaran memiliki andil paling besar menjadi faktor ketidakberhasilan dalam mencapai kesuksesan 
pembelajaran bahasa Arab. Oleh karena itu, hal tersebut merupakan sekumpulan problematika dalam pembelajaran yang harus segera dicarikan solusi terbaik.

Sejarah mencatat bahwa pesantren memiliki andil yang sangat besar dalam mengembangkan pembelajaran bahasa Arab di Indonesia. Pada mulanya orientasi pembelajaran bahasa Arab hanya terbatas untuk kebutuhan aktivitas keagamaan Islam sebagai agama mayoritas di Indonesia. Namun seiring dengan perkembangan zaman, orientasi pembelajaran bahasa Arab pun berkembang tidak hanya sebatas orientasi religious, namun juga memiliki orientasi akademik dan orientasi profesional.

Dari hasil pendataan yang dilakukan Forum Silaturahmi Pondok Pesantren (FSPP) Kabupaten Lebak, setidaknya terdapat 1.122 Pondok Pesantren (Ponpes) Salafi (Tradisional) yang tersebar di sejumlah wilayah kecamatan (http://bantenheadline.com, 2017). Belum lagi sebaran Pondok Pesantren Modern yang sedang berkembang pesat mencapai 31 pesantren di Kabupaten Lebak. Hal tersebut menjadi menarik diteliti untuk mengetahui perkembangan pembelajaran bahasa Arab yang terjadi di berbagai pesantren tersebut.

Berdasarkan latar belakang tersebut, menurut peneliti, terdapat sejumlah alasan mengapa "pembelajaran bahasa Arab" dikaitkan dengan "penerapan dan pengembangannya pada beberapa pesantren di Propinsi Banten" penting dikaji dan diteliti.

Pertama, proses pembelajaran bahasa Arab selama ini belum memenuhi standar input, standar proses, dan standar output bahkan outcome untuk mendapatkan hasil pembelajaran efektif. Kedua, bahasa Arab yang menjadi ciri khas pesantren akan sulit dikuasai dengan baik oleh santri tanpa suatu kebijakan yang memungkinkan ketercapaian tujuan pembelajaran bahasa Arab. Ketiga, pembelajaran bahasa Arab relatif masih banyak terkendala dibanding dengan pembelajaran bahasa Inggris. Hal ini menjadi menjadi motivasi untuk terus mengembangkan formula kurikulum pembelajaran bahasa Arab yang efektif sehingga dapat mengimbangi dan menyaingi perkembangan pembelajaran bahasa asing lainnya. Keempat, tujuan pembelajaran bahasa Arab pada pondok pesantren belum jelas berorientasi, bertradisi, dan berinovasi untuk kemampuan berbahasa ataukah kemampuan memahami teks karena masih berfokus kepada orientasi pengajar. Hal ini menjadi latar belakang untuk menentukan orientasi yang tepat untuk pembelajaran bahasa Arab pada pondok pesantren.

Ismail Suardi Wekke (2013), "Pendidikan Bahasa Arab dan Konstruksi Pembelajaran Moderen di Pesantren Minoritas Muslim Indonesia" menyatakan bahwa lingkungan pendidikan menjadi sebuah pilar bagi berlangsungnya praktik dalam keseharian secara kontekstual. Dalam lingkungan itulah praktik komunikasi diterapkan sesuai dengan pola pembelajaran. Kesempatan untuk berinteraksi, menggunakan kemampuan yang sudah didapatkan dalam pelajaran, memahami konteks sebuah kalimat, dan memaknai ujaran menjadi kelengkapan dalam belajar. Sehingga belajar bahasa tidak semata-mata hanya di ruang saja. Tetapi lingkungan pendidikan yang ditempati sekaligus menjadi wahana pembelajaran yang berkelanjutan. Dukungan lingkungan ini menjadi sarana sekaligus laboratorium. Pola komunikasi yang dilaksanakan dalam suasana senyatanya. Bahasa yang dituturkan sekaligus dalam mempertahanan kosakata yang sudah dipelajari. Akhirnya, kesepaduan antara hasrat, manajemen, dan pelaksanaan dengan pola terpadu membentuk penguasaan bahasa yang dapat digunakan sebagai alat komunikasi.

Mustika Wiguna, "Pengelolaan Pembelajaran Bahasa Arab yang Terintegrasi dengan Pesantren di MA Sunanul Huda dalam Meningkatkan Prestasi Siswa". Hasil penelitian tersebut menunjukkan bahwa sikap ramah namun disiplin yang ditunjukkan oleh guru Bahasa Arab menambah kemudahan dalam pembelajaran Bahasa Arab sehingga siswa tidak segan bertanya jika ada kesulitan dalam memahami materi yang sedang dipelajari.

Mohammad Thoha (2012), "Pembelajaran Bahasa Arab dengan Pendekatan Manajemen Berbasis Sekolah". Hasil penelitian tersebut menunjukkan bahwa Manajemen Berbasis Sekolah memberikan kesempatan seluas-luasnya pada pengajar bahasa Arab untuk mengaktualisasikan potensi sekolah dalam merancang sistem pembelajaran. Kesempatan ini memberikan peluang bagi 


\section{Arabi : Journal of Arabic Studies}

pengelola lembaga pendidikan agama, mengingat sebagian besar lembaga pendidikan agama telah memiliki basic yang memadai untuk pengembangan bahasa Arab.

Moch. Sony Fauzi, "Pesantren Tradisional; Akar Penyebaran Islam dan Bahasa Arab di Indonesia" menyatakan bahwa dengan sistem pengajaran yang khas, pesantren tradisional telah mampu memproduk ulama-ulama besar di Indonesia yang lewat tangan-tangan dingin mereka Islam dan bahasa Arab akan selalu menyertai dinamika berbangsa dan bernegara dalam rentangan sejarah bangsa dari masa ke masa. Jika tradisi pengkajian agama Islam dan pelestarian kitab-kitab turăts (tradisional) di pesantren-pesantren yang ada di Indonesia terus berlangsung dan selalu berkembang, maka tidak mustahil, apabila di kemudian hari nanti, Indonesia menjadi pusat pengembangan Islam dan bahasa Arab di dunia.

Rohmat (2011), "Pengajaran Bahasa Arab dengan Contextual Learning Pondok Pesantren Al Ikhlas Di Dawar, Manggis, Mojosongo, Boyolali, Jawa Tengah", menyatakan bahwa komponenkomponen pengajaran konstektual mencakup: keterkaitan bermakna; pengajaran mandiri dan kerjasama, berpikir kritis dan kreatif, membantu siswa tumbuh dan berkembang, mencapai standar tinggi dan pemikiran autentik serta strategi pengajaran kontekstual tidak didapatkan dalam pengajaran bahasa Arab Pondok Pesantren Al Ikhlas di Dawar, Manggis, Mojosongo, Boyolali, Jawa Tengah.

Berdasarkan identifikasi dan pembatasan masalah tersebut, Pertanyaan dalam penelitian ini adalah: "Bagaimana potret pembelajaran bahasa Arab pada pondok pesantren di Propinsi Banten?" dan "Bagaimana orientasi, tradisi, dan inovasi pembelajaran untuk ketercapaian tujuan pembelajaran bahasa Arab pada pondok pesantren di Propinsi Banten?"

Penelitian tentang tinjauan analisis pembelajaran bahasa Arab pada pondok pesantren di Propinsi Banten bertujuan untuk menganalisa dan mengkritisi implementasi pembelajaran bahasa Arab. Secara lebih rinci tujuan penelitian ini dapat diuraikan sebagai berikut:

1. Menganalisa berbagai kekuatan, kelemahan, peluang, dan tantangan yang terdapat pada pembelajaran bahasa Arab untuk pondok pesantren di Propinsi Banten;

2. Merekonstruksi pembelajaran bahasa Arab yang standar dari segi orientasi, tradisi, dan inovasi yang sesuai untuk pondok pesantren di Propinsi Banten ke arah yang lebih baik sebagai ciri keunggulan lembaga pendidikan Islam.

Hasil penelitian ini mempunyai beberapa signifikansi teoritis dan praktis, diharapkan dapat sebagai berikut:

1. Memberikan kontribusi ilmiah dalam aplikasi konsep pengembangan pembelajaran keterampilan berbahasa Arab yang efektif;

2. Memberikan pemahaman terhadap pengembangan pembelajaran bahasa Arab sebagai modal utama dalam mencarikan solusi berbagai persoalan dalam pendidikan bahasa Arab;

3. Menjadi inspirasi bagi para penggiat bahasa Arab dalam memajukan pembelajaran bahasa Arab, khususnya dalam pembelajaran keterampilan berbahasa Arab;

4. Memberikan kontribusi penting dalam peninjauan kembali kurikulum pembelajaran bahasa Arab pada pondok pesantren di Propinsi Banten, khususnya kurikulum pengembangan keterampilan berbahasa Arab.

\section{Metode Penelitian}

Penelitian ini merupakan penelitian kualitatif (Creswell, 1998) dengan jenis penelitian lapangan (field research) dengan orientasi pengumpulan data empiris lapangan (Donim, 2002). Peneliti secara langsung mengkaji kurikulum, mengkaji dokumen-dokumen pembelajaran, dan mengamati pembelajaran bahasa Arab pada pondok pesantren. Dengan peneliti dapat mempelajari, memahami, menggambarkan, menganalisis, dan mengkritisi kurikulum yang digunakan dalam pembelajaran (Rahmat, 2009).

Penelitian ini merupakan kajian deskriptif analisis kritis. Penelitian ini dirancang untuk pengumpulan data dalam rangka menguji hipotesis atau jawaban pertanyaan yang berkaitan 
dengan orientasi pembelajaran bahasa Arab pada program studi agama. Sedangkan analisis yang dimaksud adalah penelitian ini mencari pola dan model pembelajaran bahasa Arab yang berlangsung selama ini. Data penelitian tidak hanya dideskripsikan, tetapi juga dianalisis dan ditafsirkan sesuai dengan makna data tersebut. Adapun kritis yang dimaksud adalah penelitian ini mengomentari dan memberikan masukan terhadap realita dalam pembelajaran bahasa Arab dengan diperkuat berbagai teori pembelajaran bahasa (Sya'ban, 2005).

Peneliti memosisikan diri sebagai "instrument penelitian" yang berinteraksi langsung dengan data-data penelitian dan melakukan pemaknaan dalam konteks orientasi pembelajaran bahasa Arab pada program studi agama. Instrumen dalam penelitian kualitatif merujuk kepada diri peneliti sebagai alat pengumpul data.

Pendekatan evaluatif juga digunakan dalam penelitian ini dengan maksud mengumpulkan data tentang implementasi pembelajaran bahasa Arab pada program studi agama (Arikunto, 2010). Penelitian evaluatif pada umumnya terpusat pada rekomendasi akhir yang menyatakan bahwa suatu obyek evaluasi dapat dipertahankan, ditingkatkan, diperbaiki atau bahkan dihentikan sejalan dengan data yang diperoleh. Penelitian evaluatif dalam pendidikan mencakup bidang yang cukup luas, yaitu kurikulum, program pendidikan, proses pembelajaran, pendidik, dan peserta didik.

Data yang dikumpulkan dalam penelitian ini berasal dari hasil wawancara (interview), catatan lapangan (observasi), dan dokumentasi (analisis dokumentasi). Penggunaan metode penelitian didasarkan atas tujuan pokok penelitian ini, yaitu berusaha mendeskripsikan situasi secara komprehensif dalam konteks yang sesungguhnya berkaitan dengan pembelajaran bahasa Arab untuk program studi agama. Metode evaluasi dengan model evaluasi Goal Oriented Evaluation digunakan untuk menganalisa keberhasilan pembelajaran bahasa Arab. Model Goal Oriented Evaluation yang dikemukakan oleh Tyler merupakan pendekatan evaluasi yang menentukan peninjauan pada tujuan sejak awal kegiatan dan berlangsung secara berkesinambungan. Adapun prosedur pendekatan evaluasi Tyler sebagai berikut: 1) Perumusan tujuan yang akan diukur, 2) Pemilihan instrumen, 3) Pemilihan desain evaluasi, 4) Pengumpulan dan analisis data, dan 5) Interpretasi hasil.

Berdasarkan kualifikasinya, data yang digunakan ada dua macam, yaitu primer dan sekunder. Data primer meliputi data yang diperoleh secara langsung di lapangan yang bersumber dari obyek penelitian itu sendiri. Adapun data sekunder penelitian ini adalah berbagai macam buku dan jurnal yang membahas tentang pembelajaran bahasa Arab.

Ruang lingkup penelitian ini dibatasi kepada pembelajaran bahasa Arab pada 5 (lima) pondok pesantren tradisional dan 5 (lima) pondok pesantren modern di Kabupaten Lebak Propinsi Banten yang dipilih secara acak (random sampling). Penelitian ini dibatasi hanya untuk mengkaji secara mendalam pembelajaran bahasa Arab yang terjadi pada kedua prodi tersebut selama 3 tahun terakhir. Penulis berasumsi bahwa pokok utama dari penelitian kualitatif adalah sejauh mana kedalaman pengkajian sebuah penelitian, bukan seberapa banyak objek yang akan diteliti. Namun demikian, berbagai sumber dari beberapa program studi agama lainnya akan tetap digunakan sebagai penunjang dalam penelitian ini.

Penelitian dibagi kepada beberapa tahapan, yaitu tahap pra lapangan, tahap pekerjaan lapangan, tahap analisis data, dan tahap evaluasi data. Dalam tahap pra lapangan peneliti melakukan survei pendahuluan dalam rangka penjajagan lapangan terhadap latar penelitian, mencari data dan informasi tentang penelitian.

Dalam tahap pekerjaan lapangan, peneliti sudah memasuki dan memahami latar penelitian dalam rangka pengumpulan data. Adapun dalam tahap analisis data, peneliti melakukan serangkaian proses analisis sampai pada interpretasi data kualitatif. Sedangkan pada tahap evaluasi, peneliti melakukan berbagai konsultasi untuk mengevaluasi hasil analisis data penelitian.

Peneliti menggunakan teknik wawancara (Prastowo, 2012) (in-depth interview) (Arikunto, 2006) sebagai teknik utama untuk menggali secara mendalam informasi tentang orientasi 


\section{Arabi : Journal of Arabic Studies}

pembelajaran bahasa Arab pada pondok pesantren di Propinsi Banten. Adapun yang menjadi objek wawancara, meliputi:

1) Pimpinan Pondok Pesantren

2) Pengajar Bahasa Arab

3) Santri

Peneliti juga melakukan studi dokumentasi untuk melacak data dan informasi penunjang penelitian seperti dokumen rencana pembelajaran, materi ajar bahasa Arab, dan data lain yang terkait dengan tema penelitian. Selain itu, peneliti menggunakan teknik observasi sebagai teknik penunjang dalam mengumpulkan data penelitian. Peneliti mengumpulkan data dari lapangan dengan mengamati, mengikuti kegiatan, merekam, memotret, mencatat secara sistematis segala sesuatu yang berkaitan orientasi pembelajaran bahasa Arab pada pondok pesantren di Propinsi Banten.

Penggunaan ketiga teknik tersebut dilakukan secara saling melengkapi. Misalnya, metode wawancara diarahkan untuk mendalami dan melakukan cek ulang terhadap hasil observasi. Demikian pula metode observasi diharapkan dapat melengkapi atau cek ulang dari data yang diperoleh dari data dokumen atau sebaliknya.

Peneliti menggunakan uji triangulasi untuk menguji validitas dan reliabilitas data, meliputi uji bahan referensi, uji member check, dan konsultasi dengan para ahli. Bahan referensi digunakan oleh peneliti untuk mendukung dan membuktikan kebenaran data yang diperoleh. Member check dilakukan untuk mengetahui kebenaran data setelah dikonfirmasi kepada objek penelitian. Adapun konsultasi bertujuan untuk menambah bukti kebenaran data perspektif para ahli. Selain itu, data dapat dikatakan reliable jika menunjukkan kestabilan hasil setelah dilakukan pengecekan secara berulang-ulang.

Peneliti menggunakan teknik analisis data model Miles dan Huberman dengan kegiatan sebagai berikut:

1) Pengumpulan data yang berkaitan dengan penelitian untuk mendukung penelitian yang sedang dilakukan;

2) Penyederhanaan data (data reduction) dalam rangka memilih hal-hal pokok yang sesuai dengan fokus penelitian. Hal tersebut merupakan proses pemilahan dan pemusat perhatian pada penyederhanaan, pengabstrakan, dan transformasi data kasar yang muncul dari hasil pengumpulan data;

3) Penyajian data (display data) meliputi proses klasifikasi data dalam rangka memudahkan dalam analisis dan penyimpulan data (Meleong, 2002). Bentuk yang terbiasa digunakan dalam penyajian data penelitian kualitatif lazim dengan menggunakan teks naratif;

4) Verifikasi data dalam rangka penarikan kesimpulan yang diperkuat dengan bukti-bukti dari data-data yang telah dikumpulkan. Verifikasi dilakukan untuk menghilangkan keraguan dalam penarikan kesimpulan dan menghindari penarikan kesimpulan menyimpang.

Selain itu, peneliti menggunakan metode analisis data induktif untuk memahami data dan informasi yang diperoleh dari lapangan dan kemudian mensintesiskan ke dalam beberapa kategori sesuai dengan teori yang relevan (Anggoro, 2007).

\section{Pembelajaran Bahasa Arab di Pondok Pesantren Modern}

Pembelajaran bahasa Arab di Pondok Pesantren Modern ditargetkan untuk menguasai pondasi dasar bahasa Arab, yaitu nahwu-sharf serta balāghah. Di sisi lain, pembelajaran bahasa Arab dapat menggunakan pondasi tersebut di dalam membaca kitab kuning klasik berbahasa Arab. Pengajar bahasa Arab menggunakan metode induktif dalam pembelajaran bahasa Arab, yaitu diawali dengan pemberian contoh-contoh kaidah, dan kemudian penjelasan tentang kaidah yang sedang dipelajari. Ketika santri belum mengetahui beberapa kosakata, maka mereka mencari makna melalui kamus, yaitu kamus Mahmud Yunus dan kamus al-Munjid. Teknik mengajar yang digunakan oleh guru bahasa Arab menggunakan teknik ceramah, muthala'ah, dan tarwiyah. 
Setelah materi disampaikan, guru bahasa Arab memberikan latihan terkait kaidah yang dipelajari secara lisan/tulisan dan bersifat perorangan.

Para santri termotivasi untuk belajar bahasa Arab karena merupakan bahasa Alquran dan bahasa yang digunakan oleh ahli surga. Meskipun di lingkungan pesantren, ditemukan juga bahwa tidak semua santri mampu menguasai pelajaran-pelajaran bahasa Arab di dalam kelas maupun di luar kelas. Menurut informasi santri, guru bahasa Arab pun terkadang menggunakan media pembelajaran selain buku, seperti penayangan film berbahasa Arab dan penggunaan lab bahasa. Hal tersebut sudah tentu dapat meningkatkan minat dan motivasi santri dalam belajar bahasa Arab.

\section{Pembelajaran bahasa Arab di Ponpes Al-Hidayah}

Pembelajaran bahasa Arab di Pondok Pesantren Al-Hidayah mengacu kepada Kurikulum 2013. Pembelajaran dimulai dari mengenalkan kosakata. Kosakata benda-benda yang ada di sekeliling pondok, kemudian tentang warna dan bentuk, setelah itu diajarkan menyusun kalimat. Teknik pengajaran yang digunakan oleh pengajar, yaitu teknik ceramah. Selain itu, pembelajaran bahasa Arab didukung oleh kebijakan pesantren yang mewajibkan para santri untuk menggunakan bahasa asing dalam komunikasi sehari-hari. Penggunaan bahasa asing, yaitu Arab dan Inggris dilakukan secara bergantian selama seminggu sekali.

Keadaan santri di setiap angkatan terdiri dari 2 (dua) kelas untuk santriwan dan 1 (satu) kelas untuk santriwati. Kebijakan Pondok Pesantren Al-Hidayah hanya mengalokasikan pembelajaran bahasa Arab sebanyak 4 jam dalam seminggu. Dengan demikian, setiap malam selalu diadakan kegiatan pendalaman materi yang diajarkan di kelas. Pembelajaran bahasa Arab di AlHidayah lebih berfokus mengikuti alur kurikulum 2013.

Adapun minat dan motivasi santri dalam belajar bahasa Arab bervariatif. Terdapat santri dengan minat dan motivasi tinggi serta juga sebaliknya. Pengajar bahasa Arab tidak henti-hentinya untuk terus berusaha meningkatkan minat dan motivasi mereka dengan berbagai cara, seperti menasehati dan berdialog. Selain itu, santri yang telah lulus menjadi alumni diberikan kesempatan untuk menjadi pengajar sebagai bentuk pengabdian mereka kepada pondok pesantren.

Pembelajaran bahasa Arab di Ponpes Al-Hidayah sangat terbantu dengan adanya kegiatan Hidayah Arabic Course yang diselenggarakan penuh selama satu minggu berselingan dengan Hidayah English Course. Kegiatan ini bersifat wajib dan dalam pendampingan kakak kelas. Beberapa santri termotivasi untuk belajar bahasa Arab dengan tujuan untuk menyenangkan orangtua yang sudah berjuang memberikan pendidikan yang layak bagi mereka.

Pembelajaran kosakata diberikan melalui pemeragaan dari guru. Setelah itu, santri diberikan latihan dalam bentuk pertanyaan lisan. Setiap 3 bulan sekali, guru bahasa Arab selalu mengadakan kegiatan perlombaan khusus untuk materi bahasa Arab, dalam bentuk lomba mufradat, lomba menyanyi dalam bahasa Arab, dan sebagainya.

Pembelajaran bahasa Arab didukung dengan kegiatan nahdlatul lughah dengan struktur pelaksana terdiri ustadz/ah dan qism al-lughah. Kegiatan ini terdiri dari penguasaan mufradāt, pelaksanaan muhādharah, dan penerapan muhādatsah di setiap minggu. Pembelajaran mufradāt dibagi ke dalam lima kelas, yaitu: kelas isim, kelas fi'il wa fá'il, kelas mashdar, kelas kalimat ashïlah, dan kelas kaifa at-thariqah li tahadatsh shahihan bin nahwi wakadzalika bish sharfi.

Tujuan belajar bahasa Arab ditargetkan untuk memahami kandungan Alquran, di samping juga untuk memahami kandungan kitab-kitab referensi klasik berbahasa Arab. Bi'ah lughawiyah teramat penting untuk penguasaan keterampilan aktif berbahasa Arab. Hal ini dilakukan dengan teladan dari guru yang selalu berkomunikasi dengan bahasa Arab, tiada hari ditemui komunikasi dengan bahasa Indonesia. Jika santri menemukan kosakata yang sulit, maka mereka dapat bertanya kepada kakak kelas. Mereka wajib berkomunikasi dengan bahasa Arab selama 3 hari dalam seminggu, yaitu Senin, Selasa, dan Rabu. 


\section{Arabi : Journal of Arabic Studies}

Pimpinan pesantren merupakan alumni dari pondok pesantren Darussalam Gontor. Dengan demikian, berbagai model dan perangkat pembelajaran mayoritas diadopsi dari pengalaman mereka ketika menimba ilmu di pondok pesantren Darussalam Gontor.

Setiap bulan guru mengadakan perlombaan terkait materi bahasa Arab, tepatnya setiap malam jumat dan malam sabtu. Hal ini bertujuan untuk meningkatkan semangat santri dalam belajar bahasa Arab. Banyak santri termotivasi belajar bahasa Arab supaya dapat mempermudah dalam proses menghafal Alquran, sehingga mayoritas santri lebih tinggi minatnya kepada bahasa Arab dibanding kepada bahasa Inggris.

Pembelajaran bahasa Arab didukung dengan kegiatan wajib berbicara bahasa Arab, sehingga santri tidak boleh menggunakan bahasa Indonesia dalam berkomunikasi sehari-hari. Seminggu menggunakan bahasa Arab, seminggu menggunakan bahasa Inggris, dan hal tersebut terus menerus dilakukan secara kontinyu.

Para santri ditargetkan menjadi ulama ketika lulus dari pesantren. Dengan demikian, mereka dituntut untuk menguasai bahasa Arab dalam rangka memahami kandungan Alquran dan juga kandungan kitab referensi klasik berbahasa Arab. Pembelajaran bahasa Arab dimulai semenjak pagi dalam bentuk pemberian kosakata baru dengan dipandu oleh kakak kelas.

Setelah menjelaskan materi, guru memberikan latihan untuk mengetahui sejauh mana tingkat pemahaman santri. Jika terdapat santri yang masih belum memahami pelajaran, maka guru akan mengulangi penjelasan materi sampai santri dapat memahaminya dengan baik. Bahkan di setiap malam para santri melakukan muraja'ah sebagai pelajaran tambahan di kelas. Selain itu, terdapat program tahfiz Alquran yang dapat menunjang kelancaran proses pembelajaran bahasa Arab.

Pembelajaran bahasa Arab ditargetkan agar santri dapat berkomunikasi secara aktif dan pasif dengan menggunakan bahasa Arab. Motivasi santri belajar bahasa Arab pun supaya dapat menjadi seorang yang berilmu. Bahasa Arab merupakan alat untuk memahami berbagai referensi ilmu di dalam bahasa Arab.

Pembagian kelas dilakukan ke dalam kelas A dan B. Kelas A diperuntukkan bagi santri dengan nilai lebih baik dibanding kelas B. Dengan alasan agar potensi-potensi buruk yang ada di dalam santri kelas B bisa dihindari oleh santri kelas A. Karena biasanya nilai yang minus identik juga dengan karakter yang minus.

\section{Pembelajaran bahasa Arab di Pondok Pesantren Al-Bayan}

Pembelajaran bahasa Arab di Pondok Pesantren Al-Bayan misalnya menggunakan konsep pembelajaran nazhariyat al-furü'/separated system. Bahasa Arab dianggap sebagai system yang harus dibagi ke dalam beberapa bagian yang harus diajarkan secara terpisah, seperti nahw, sharf, balaghah, dalalah, dan sebagainya.

Metode pembelajaran yang digunakan pada pembelajaran salah satu unsur atau keterampilan bahasa tersebut diawali dengan mengucapkan salam, kemudian memberikan kosakata yang terkandung dalam materi yang akan diajarkan. Pembelajaran nahw misalnya dilakukan secara induktif. Para santri diberikan contoh-contoh kaidah yang hendak diajarkan, lalu secara otomatis mereka akan memahami keunikan dari kaidah yang diajarkan melalui contoh-contoh. Bahkan pengajar bahasa Arab di sana mengklaim metode tersebut sangat sesuai dengan cita-cita Kurikulum 2013 yang bertujuan membuat anak aktif dalam menemukan contoh-contoh lain terkait kaidah bahasa Arab yang sedang diajarkan.

Pemahaman santri tentang kaidah yang diajarkan akan dievaluasi atau dicek kesesuaian pemahamannya. Jadi, pengajar bertugas meluruskan pemahaman yang kurang tepat berasal dari kesimpulan contoh-contoh kaidah yang disajikan. Evaluasi tersebut dilakukan dalam bentuk lisan dan tulisan. Selain itu, pembelajaran bahasa Arab didukung oleh kebijakan pesantren yang mewajibkan para santri untuk menggunakan bahasa asing dalam komunikasi sehari-hari. Penggunaan bahasa asing, yaitu Arab dan Inggris dilakukan secara bergantian selama seminggu sekali. 
Dengan kebijakan tersebut, pihak pesantren dapat melihat kecenderungan motivasi para santri dalam menggunakan bahasa Arab atau Inggris. Penuturan pengajar mengungkapkan bahwa mayoritas santri lebih cenderung termotivasi menggunakan bahasa Arab dalam berkomunikasi. Alasannya sederhana, para santri lebih mudah untuk melafalkan bahasa Arab dibandingkan dengan bahasa Inggris. Jadi, kecenderungan terjadi dalam lingkup pelafalan bahasa.

Kebijakan pesantren pun menuntut pembelajaran bahasa Arab dilakukan dengan membagi para santri ke dalam beberapa kelompok kelas, yaitu Kelas A, Kelas B, dan Kelas C. Kelas A diperuntukkan bagi santri yang lebih menguasai bahasa Arab, dibanding Kelas B, apalagi Kelas C. Hal ini dilakukan untuk menyesuaikan kelompok belajar dengan latar belakang pendidikan masingmasing santri. Para santri yang memiliki kemampuan lebih akan dikelompokkan dengan santrisantri selevel mereka.

Pembelajaran bahasa Arab terkadang dilakukan dengan menggunakan media pembelajaran elektronik. Namun hal tersebut disesuaikan dengan kepadatan kegiatan belajar para santri. Pengajar terkadang menayangkan film-film berbahasa Arab untuk seluruh santri di luar jam pelajaran dengan tujuan meningkatkan motivasi mereka dalam belajar bahasa Arab.

Alokasi waktu yang diberikan pihak pesantren untuk pembelajaran bahasa Arab total mencapai 45 jam dalam seminggu. Waktu tersebut dibagi ke dalam 3 kali pertemuan dalam sehari. Masing-masing pertemuan diberikan alokasi waktu mulai dari 2 jam, 3 jam, bahkan 6 jam. Dengan demikian, pesantren ini sangat memberikan perhatian penuh untuk pembelajaran bahasa Arab.

Jika alokasi waktu yang diberikan untuk pembelajaran bahasa Arab masih dinilai kurang, maka wali kelas diberikan waktu untuk kegiatan tambahan dengan nama muwajahah. Kegiatan ini hanya dilakukan pada waktu malam hari dan tidak hanya untuk membahas tentang pembelajaran bahasa Arab, namun juga untuk membahas berbagai permasalahan yang dialami oleh para santri. Kegiatan ini bisa dibilang sesi curhat untuk para santri. Kegiatan ini hanya diberi alokasi waktu selama 2 jam seminggu.

Pondok pesantren Al-Bayan memiliki program unggulan, yaitu program tahfidz. Program ini sudah berjalan 3 tahun untuk para santriwan dan sudah berjalan 2 tahun untuk para santriwati. Alhamdulillah beberapa santri sudah mampu menghafal Alquran sebanyak 4 juz untuk jenjang menengah pertama.

\section{Pembelajaran bahasa Arab di Pondok Pesantren Al-Mizan}

Pembelajaran bahasa Arab di Pondok Pesantren Al-Mizan membatasi pembelajaran nahwu dan balaghah baru pada kelas 4, 5, dan 6. Selain itu, pembelajaran bahasa Arab didukung oleh kebijakan pesantren yang mewajibkan para santri untuk menggunakan bahasa asing dalam komunikasi sehari-hari. Penggunaan bahasa asing, yaitu Arab dan Inggris dilakukan secara bergantian selama seminggu sekali.

Pondok Pesantren Al-Mizan memiliki kebijakan bagi para santri yang memperoleh nilai di bawah standar yang ditetapkan. Mereka dipanggil satu per satu untuk diidentifikasi kekurangankekurangan yang menyebabkan minimnya nilai mereka. Setelah itu, mereka akan diberikan jam tambahan di luar jadwal regular untuk mendapatkan pendalaman materi.

Kebijakan Pondok Pesantren Al-Mizan hanya mengalokasikan pembelajaran bahasa Arab sebanyak 8 jam dalam seminggu. Namun penerapan disiplin kebahasaan yang dibuat oleh pihak pondok pesantren sedikit banyak dapat membantu pemahaman pembelajaran bahasa Arab.

Pondok pesantren Al-Mizan memiliki program unggulan sama dengan Al-Bayan, yaitu program tahfidz. Selain itu, Al-Mizan memiliki program unggulan di bidang kebahasaan, yaitu jam'iyyah al-khathābah. Program ini mempersiapkan para santri untuk lancer berpidato dalam berbahasa Arab.

\section{Pembelajaran bahasa Arab di Pondok Pesantren Darel Azhar}

Pembelajaran bahasa Arab di Pondok Pesantren Darel Azhar memadukan model pembelajaran yang diselenggarakan oleh Pondok Modern Gontor dan Kementerian Agama. 


\section{Arabi : Journal of Arabic Studies}

Pembelajaran bahasa Arab di Darel Azhar menggunakan metode langsung (direct method) dengan berbagai alat bantu.

Evaluasi pembelajaran bahasa Arab dilakukan dengan berbagai macam model evaluasi. Pertama, anak-anak diperintahkan untuk maju satu persaatu memperagakan. Kedua, latihan kosakata di luar kelas dari kakak kelas ke adik kelas. Ketiga, latihan Muhadatsah di setiap selasa dan jumat. Keempat, latihan tulis di setiap hari.

Materi-materi yang diajarkan di Darel Azhar meliputi muhādatsah, muthāla'ah, tarjamah, dan mufradāt. Kemudian para santri juga mengerjakan berbagai ibadah amaliyah, seperti membaca Alquran, dan membaca doa. Para santri yang melanggar peraturan pondok pesantren akan diberikan sanksi, mulai dari sanksi ringan sampai dengan sanksi berat. Sanksi untuk santriwan bisa sampai dicukur gundul dan sanksi untuk santriwati dalam bentuk penggunaan jilbab hijau, kuning, dan merah.

Kebijakan Darel Azhar mewajibkan lingkungan berbahasa Arab dan Inggris. Terdapat sanksi bagi santri yang melanggar. Hal ini serupa dengan kebijakan pada Pondok Pesantren Al-Bayan, AlMizan, dan Al-Hidayah.

Media pembelajaran bahasa Arab pun digunakan secara bervariatif, meliputi pengeras suara, infocus, dan kaset. Pengajar bahasa Arab pun berpendapat bahwa 80\% pembelajaran di Darel Azhar adalah bahasa Arab. Mayoritas buku pelajaran sudah menggunakan bahasa Arab dengan pengantar bahasa Arab pula. Buktinya terdapat beberapa lulusan Darel Azhar yang langsung diterima untuk melanjutkan studi di Mesir.

\section{Pembelajaran bahasa Arab di Pondok Pesantren Darunna'im}

Pembelajaran bahasa Arab di Pondok Pesantren Darunna'im sangat terbantu dengan kebijakan pesantren yang mewajibkan mahasiswa berkomunikasi sehari-hari dengan menggunakan bahasa Arab. Para santri baru diberikan waktu selama 2 bulan toleransi untuk beradaptasi sampai bisa menggunakan bahasa Arab. Setelah itu mereka diwajibkan untuk berkomunikasi dengan bahasa Arab tanpa toleransi lagi. Para santri dituntut minimal dapat menguasai kosakata bahasa Arab yang digunakan sehari-hari supaya mereka dapat berkomunikasi dan bersosialisai dengan teman-temannya.

Dalam pembelajaran bahasa Arab, para pengajar lebih menekankan kepada penugasan para santri agar mereka mengembangkan apa yang didapatkan di kelas. Sedangkan tugas-tugas bersumber dari buku yang digunakan. Jadi, setiap santri memiliki buku tugas untuk mengawasi dan menilai tugas-tugas yang telah dikerjakan oleh santri dari setiap pengajar.

Terkait kebijakan lingkungan berbahasa, pengajar Darunna'im berpendapat bahwa lingkungan pesantren diibaratkan laboratorium alam. Dengan sendirinya para santri akan merasakan penasaran untuk mengetahui kosakata Arab benda-benda yang terdapat di pondok pesantren. Sedangkan klasifikasi kelas dilakukan dalam bentuk asrama, yaitu asrama kelas 1, asrama kelas 2, dan asrama kelas 3. Hal ini bertujuan untuk membedakan pemberian materi bahasa Arab sesuai dengan tingkatan para santri. Setiap angkatan dibagi ke dalam 4 (empat) kelas disesuaikan dengan nilai santri.

Selain jadwal regular, pembelajaran bahasa Arab diselenggarakan melalui kursus pengulangan kosakata selama satu minggu. Media pembelajaran yang digunakan masih mengandalkan kamus dan kitab. Biasanya kosakata yang sudah diajarkan biasanya ditulis dan ditempel di pohon-pohon dengan tujuan membantu santri untuk mengingat kosakata yang telah diajarkan.

Alokasi waktu belajar bahasa Arab untuk santri baru sebanyak 4 kali pertemuan dalam satu minggu. Sedangkan alokasi waktu untuk santri kelas 2 dan 3 sebanyak 2 kali pertemuan dalam seminggu. Minat dan motivasi santri dalam belajar bahasa Arab tergolong bagus karena mereka menganggap bahasa Arab lebih mudah untuk dipelajari dan diucapkan.

Selain itu, Darunnaim juga memiliki program lain untuk meningkatkan keterampilan bahasa Arab santri, yaitu kegiatan muwājahah (semacam kursus) dengan pengajar adalah kakak kelas 
paling senior yang dinilai mumpuni. Ada juga kegiatan Muhādatsah dalam dua minggu sekali diselingi dengan kegiatan drama berbahasa Arab atau Inggris.

\section{Simpulan}

Hadirnya sistem pendidikan pada pondok pesantren modern merupakan keniscayaan dalam sistem pendidikan di Indonesia pada umumnya. Sistem ini dianggap tepat bagi dunia pesantren (masa kini) untuk mempersiapkan anak didiknya menjadi pribadi yang siap menghadapi tuntutan zaman. Di antara yang bisa disimpulkan tentang pondok pesantren modern antara lain: sistem pendidikan pondok pesantren modern, sebenarnya merupakan kelanjutan dari sistem pendidikan pondok pesantren salafiyah, di mana kemunculannya bertujuan untuk beradaptasi dengan tuntutan zaman yang ada. Sistem pendidikan pondok pesantren modern, berupaya memadukan sistem tradisional dengan sistem modern yang berkembang di tengah masyarakat. Begitu pula sistem pendidikan pondok pesantren modern, lebih terbuka untuk mempelajari kitab/kitab kontemporer di samping kitab/kitab klasik. Salah satu ciri khas pondok modern adalah bahasa yang digunakan oleh elemen pondok pesantren modern adalah bahasa Arab dan bahasa Inggris sebagai upaya menjawab tantangan zaman yang dilaluinya.[]

\section{Daftar Rujukan}

Abd. Wahab, Muhbib. 2009. Pemikiran Linguistik Tammam Hassan dalam Pembelajaran Bahasa Arab. Jakarta: Ceqda UIN Jakarta.

Ahmadi. 2014. “Analisis Kontrastif dan Analisis Kesalahan dalam Pembelajaran Bahasa Arab sebagai Second Language”, at-Tajdid: Jurnal Ilmu Tarbiyah, Vol. 3, No. 1.

Anggoro, M. Toha. 2007. Metode Penelitian. Jakarta: Universitas Terbuka.

Arikunto, Suharsimi. 2010. Prosedur Penelitian: Suatu Pendekatan Praktik. Jakarta: Rineka Cipta, Cet. 14.

Azzuhri, Muhandis. 2009. "Metode dan Media Pembelajaran Bahasa Arab Berbasis Internet di Era Teknologi Informasi", Jurnal Insania, Vol. 14, No. 3.

Creswell, John W. 1998. Qualitative Inquiry and Research Design: Choosing Among Five Traditions. Thousand Oaks, London dan New Delhi: Sage Publication,.

Donim, Sudarwan. 2002. Menjadi Peneliti Kualitatif. Bandung: Pustaka Setia.

Effendy, Ahmad Fuad. 2005. Metodologi Pengajaran Bahasa Arab. Malang: Misykat.

Fahrurrozi, Aziz. 2014. "Pembelajaran Bahasa Arab: Problematika dan Solusinya", Arabiyat : Jurnal Pendidikan Bahasa Arab dan Kebahasaaraban, Vol. 1. No. 2.

Fauzi, Moch. Sony. 2007. "Pesantren Tradisional; Akar Penyebaran Islam dan Bahasa Arab di Indonesia", Jurnal Lingua, Vol. 2, No. 2.

Garancang, Sabaruddin. 2010. "Problematika Pengajaran Bahasa Arab pada Perguruan Tinggi Islam”, Jurnal Sosio-Religia, Vol. 9, No. 3.

Handriawan, Dony. 2015. "Mempertegas Kembali Arah Pembelajaran Bahasa Arab (Perspektif Budaya terhadap Tradisi Belajar Bahasa Arab di Indonesia", Jurnal al-Mahara, Vol. 1, No. 1.

Islam, Asep Muhammad Saepul. 2015. "Faktor Demotivasi Pembelajaran Bahasa Arab dalam Perspektif Siswa Madrasah," Arabiyat : Jurnal Pendidikan Bahasa Arab dan Kebahasaaraban Vol. 2, No. 1.

Meleong, Lexy J. 2002. Metode Penelitian Kualitatif. Bandung: Remaja Rosda Karya. 
Arabi : Journal of Arabic Studies

Muradi, Ahmad. 2016. "Pengembangan Kompetensi Guru Bahasa Arab Melalui IMLA Sebagai Organisasi Profesi”, Arabi: Journal Of Arabic Studies, Vol. 1, No. 2.

Prastowo, Andi. 2012. Metode Penelitian Kualitatif dalam Perspektif Rancangan Penelitian. Yogyakarta: Ar-Ruzz Media.

Rahmat, Pupu Saeful. 2009. "Penelitian Kualitatif”, Jurnal Equilibrum, Vol. 5, No. 9.

Rianto, Bambang. 2014. "Implementasi Program Pembelajaran Bahasa Arab di Sekolah Dasar di Kota Gorontalo", Jurnal Pembaharuan Pendidikan Islam, Vol. 1, No. 1.

Rohmat. 2011. "Pengajaran Bahasa Arab dengan Contextual Learning Pondok Pesantren Al Ikhlas Di Dawar, Manggis, Mojosongo, Boyolali, Jawa Tengah”, Lingua, Vol. 6, No. 3.

Sapri. 2008. "Metode Pembelajaran Bahasa Arab: antara Tradisional dan Modern", Jurnal Insania, Vol. 13. No. 3.

Subur. 2006. "Pendekatan dan Strategi Pembelajaran Bahasa Arab", Jurnal Insania, Vol. 11, No. 2.

Sya’ban, Ali. 2005. Teknik Analisis Data Penelitian. Jakarta: UHAMKA.

Thoha, Mohammad. 2012. "Pembelajaran Bahasa Arab dengan Pendekatan Manajemen Berbasis Sekolah", Okara, Vol. 1, No. 7.

Thu'aimah, Rusydi Ahmad. 1989. Ta'lim al-'Arabiyyah li Ghair al-Nathiqin biha: Manahijuhu wa Asalibuhu. Rabat: ISESCO.

Wekke, Ismail Suardi. 2013. "Pendidikan Bahasa Arab dan Konstruksi Pembelajaran Moderen di Pesantren Minoritas Muslim Indonesia", Simposium Isu-Isu Sejarah dan Tamadun Islam (SISTI II) 2013, Institut Kajian Rantau Asia Barat (IKRAB), Universiti Kebangsaan Malaysia.

Wiguna, Mustika. 2017. "Pengelolaan Pembelajaran Bahasa Arab yang Terintegrasi dengan Pesantren di MA Sunanul Huda dalam Meningkatkan Prestasi Siswa", Prosiding Seminar Nasional Pendidikan 2017. ISBN: 978-602-50088-0-.1

Winarsih, Suko. 2013. "Representasi Bahasa dalam Pertarungan Simbolik dan Kekuasaan", Jurnal Lingua Scientia, Vol. 5, No. 1. 